\title{
The role of monetary transmission channels in transmitting oil price shocks to prices in ASEAN - 4 countries during pre- and post - global financial crisis
}

\begin{abstract}
This paper examines the vulnerability of domestic prices against oil price shocks by considering the direct and indirect effects of oil price on consumer price index, which occur through the known channels of the monetary transmission mechanism. We consider interest rate, exchange rate, domestic credit, and share price during the periods before and after the global crisis of 2007-2009 in the ASEAN-4 (Association of Southeast Asian NationsIndonesia, Malaysia, the Philippines and Thailand) countries. Using the structural vector auto regression model and monthly data (2002 month 1-2013 month 4), the results indicate that pre-crisis - with the exception of Indonesia, which is not much influenced by oil pricesthere is no indirect influence, but there is a considerable direct effect of oil price on consumer price index for all countries. Post-crisis, the oil price transmits strongly to consumer price index indirectly, although the direct effect of oil price on consumer price index is still extensive. Policymakers can target domestic prices via share prices and exchange rates.
\end{abstract}

Keyword: Oil price shock; Interest rate; Exchange rate; Domestic credit; Stock price; Monetary transmission 